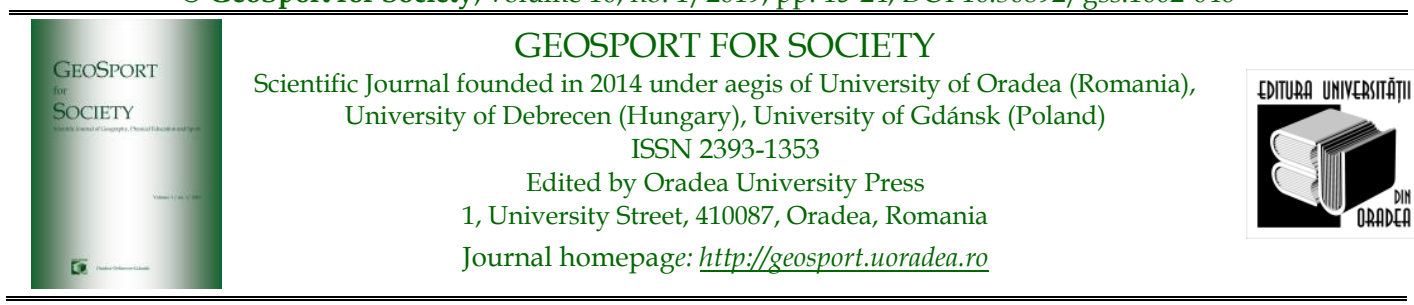

\title{
Analysis of the North Great Plain Region's Accommodation Supply with Special Focus on Sport and Wellness Elements
}

\author{
Andrea Lenténé PUSKÁS 1*, Melinda BÍRÓ 2, Péter HÍDVÉGI ${ }^{3}$, \\ Anikó MOLNÁR ${ }^{4}$, Lajos LENTE ${ }^{5}$, József Márton PUCSOK ${ }^{6}$
}

1. University of Debrecen, Institute of Sport Sciences, Egyetem tér 1., 4032, Debrecen, Hungary, e-mail: lpandrea@sport.unideb.hu

2. University of Debrecen, Institute of Sport Sciences, Egyetem tér 1., 4032, Debrecen, Hungary, e-mail: biro.melinda@sport.unideb.hu

3. University of Debrecen, Institute of Sport Sciences, Egyetem tér 1., 4032, Debrecen, Hungary, e-mail: hidvegi.peter@sport.unideb.hu

4. University of Debrecen, Department of Sports Management, Faculty of Economics and Business, Böszörményi street 138., 4032, Debrecen, Hungary, e-mail: miller.e.annie@gmail.com

5. University of Debrecen, Institute of Sport Sciences, Egyetem tér 1., 4032, Debrecen, Hungary, e-mail: lente@sport.unideb.hu

6. University of Debrecen, Institute of Sport Sciences, Egyetem tér 1., 4032, Debrecen, Hungary, e-mail: pucsok.jozsef@sport.unideb.hu

* Corresponding author

Citation: Puskás A. L., Bíró M., Hídvégi P., Molnár A., Lente L., Pucsok, J. M. (2019). Analysis of the North Great Plain Region's Accommodation Supply with Special Focus on Sport and Wellness Elements. Geosport for Society, 10(1), 15-24. https://doi.org/10.30892/gss.1002-046

Article history: Received: 09.01.2019; Revised: 20.03.2019; Accepted: 28.03.2019, Available online: 06.05.2019

\begin{abstract}
Tourism is one of the most dynamically growing sectors in the world. One of the most significant tourism products of Hungary and the Northern Great Plain region is health tourism. In our research, we examined the offer of wellness and sports services of 39 hotels in the Northern Great Plain re-gion, broken down by the classification of these hotels. The results show that wellness elements are present in most of the hotels (84.6\%), which is an element of competitiveness. Many hotels also include the word wellness in their name, which can be used in the promotion. At $35.9 \%$ of ho-tels, leisure sports are also on offer, this kind of sports service is greatly demanded by health-conscious consumers. The development of wellness and sports services can provide prevention and health retention for the consumers during their stay, besides delivering fun and entertain-ment.
\end{abstract}

Keywords: Health tourism, North Great Plain region, wellness, sport services 


\section{Introduction}

Tourism is today one of the fastest growing sectors, and its importance in Hungary is becoming increasingly significant as it can stimulate the economy to stimulate economic growth and improve economic balance (Árva et al., 2008; Darabos, 2015; Hegedűs, 2006; Herman, 2017, 2018; Ilie et al., 2017; MudruczóSzennyesy, 2005). It can promote the economic catching-up of underdeveloped regions, preserving their natural, cultural values, and improving the living conditions of the population (Michalkó and Rácz, 2011).

Health tourism in Hungary has long been a development priority. In the New Széchenyi Plan (2011) Healing Hungary-Health Industry Program, the development priority is two-pole, one is the development of tourism based on the health industry, and the other is the development of the thermal health industry. Hungarian health tourism is a brand that attracts not only a lot of domestic tourists but also a lot of foreign tourists in the motivation of destination choice (Sőrés, 2013; Müller et al., 2011; Dávid et al., 2013; Lengyel, 2016; Müller, 2018).

Tourism is one of the flagships of the Northern Great Plain region, as the spa and thermal water stock is outstanding among the region's features, which can provide a good chance for several cities to compete in tourist destinations.

Among the tourist attractions, several Hungarian tourism regions also report on the success of spa-based bath developments (Müller et al., 2009; Kerényi et al., 2009; Müller and Szabó, 2009; Barta et al., 2011; Bozóti, 2015; Bakucz et al., 2016; Müller et al., 2016a, 2016b).

Domestic research on the Northern Great Plain region also highlights the region's health tourism product development, in which bath developments also occupy a central place (Müller and Könyves, 2006; Müller and Kórik, 2009; Molnár et al., 2010; Lövei-Kalmár, 2017; Darabos and Nagy, 2018). Quality development is the backbone of success as the expansion of quality supply is an element of competitiveness (Go-Govers, 2000; Rulle et al., 2010).

Several studies report that tourists require different health-care and wellness elements during their travel. Tourism trends (Myers et al., 2000) also show that with an active lifestyle becoming more widespread the active recreational activities are getting more and more popular as well (Kiss and Török, 2001; Sziva, 2010). The availability of these services may be suitable for designing a destination health tourism brand and influencing the destination choice of tourists, thus increasing guest satisfaction as well (Kincses, 2005; Müller et al., 2018).

\section{Literature review}

Tourism contributes to the performance of several other sectors of the national economy as well. However, the most robust relationship is with the accommodation and catering industry, with a share of $1.6 \%$ of total domestic GDP in 2007. If we compare the Northern Great Plain region to the national average, we get a better picture, as in the area this rate was $1.8 \%$. Thus, the economy of the North Great Plain region as a national economic sector has a higher importance than the national average (Mező and Maczik, 2010). 
At the end of July 2017, 3411 commercial accommodations were registered in Hungary, where more than 98,000 rooms and 352,000 beds provided the conditions for the reception of tourists. On July 31, 2017, 1094 hotels with 62,000 rooms and $43 \%$ of all commercial lodging facilities $(151,000$ beds $)$ provided tourists with accommodation. The number of functioning accommodations and seats has slightly increased compared to the statistics of 2016. The number of functioning hotels has in-creased by almost 200 since 2010, displaying a $22 \%$ increase in the number of seats. The expansion of the accommodation was necessitated by the increasing demand, as the volume of domestic and international tourism has also increased and is growing steadily.

$50 \%$ of the Hungarian population took part in a multi-day trip for domestic tourism at least once in 2017. The shorter, 1-3-night trips, which were chosen by $42 \%$ of tourists, were the most popular, with only $25 \%$ of tourists picking a longer one. In 2017, the population spent 58 million days on a multi-day trip during 14 million travels, $0.4 \%$ and $1.8 \%$ less than in 2016 , respectively. In 2017, hotels were the most popular among commercial accommodation establishments, where the share of time spent rose from 30 to $32 \%$ (KSH, 2017).

In recent years, however, there has been a fluctuating but positive trend for foreign arrivals. From 2010 to 2017, the number of international visitors increased by $38 \%$ over the seven years, with overnight trips up by $29 \%$ and multi-day trips by 66\% (KSH, 2017).

The table below shows the regional distribution of the number of guests between 2015 and 2017. The data shows that the North Great Plain region is the 5th most touristic tourist region, preceded by Budapest and Central Danube region, Lake Balaton, Western Transdanubia, and Northern Hungary. The number of guests arriving in the North Great Plain region between 2015 and 2017 realized growth in demand (table 1).

Table 1. Regional distribution of guests in 2015-2017

\begin{tabular}{|c|c|c|c|c|c|c|c|c|c|c|c|}
\hline 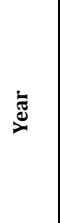 & 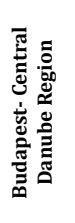 & 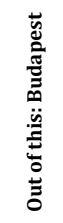 & 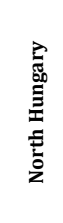 & 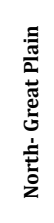 & 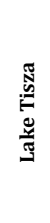 & 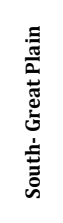 & 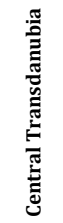 & 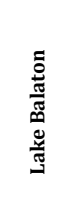 & 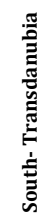 & 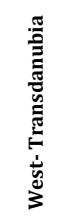 & : \\
\hline \multicolumn{12}{|c|}{ Guests (thousand) } \\
\hline 2015 & 4389 & 3805 & 951 & 720 & 111 & 690 & 438 & 1573 & 426 & 1105 & 10403 \\
\hline 2016 & 4711 & 4085 & 1008 & 759 & 105 & 730 & 499 & 1692 & 450 & 1163 & 11117 \\
\hline 2017 & 4988 & 4273 & 1083 & 821 & 134 & 818 & 552 & 1788 & 478 & 1222 & 11884 \\
\hline
\end{tabular}

The table below shows the number of guest nights and its regional differences between 2015-2017. We can state that the region is also ranked $5^{\text {th }}$ in this indicator, similarly to the number of guests. The number of guest nights in the North Great Plain region also increased from 2015 to 2017 (table 2). 
Table 2. The regional development of guest-nights between 2015-2017

\begin{tabular}{|c|c|c|c|c|c|c|c|c|c|c|c|}
\hline$\stackrel{\check{\Xi}}{\check{\nu}}$ & 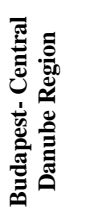 & 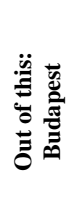 & 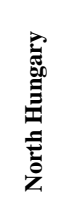 & 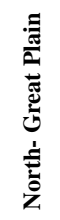 & 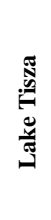 & 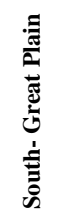 & 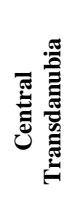 & 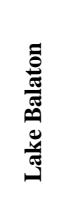 & 吾 & 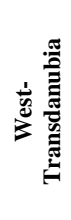 & 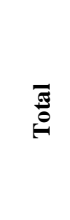 \\
\hline \multicolumn{12}{|c|}{ Nights (thousand) } \\
\hline 2015 & 9887 & 8768 & 2149 & 1945 & 309 & 1609 & 1009 & 5078 & 1023 & 2878 & 25888 \\
\hline 2016 & 10579 & 9323 & 2280 & 2055 & 300 & 1710 & 1165 & 5452 & 1052 & 3037 & 27629 \\
\hline 2017 & 11462 & 10072 & 2446 & 2161 & 367 & 1913 & 1312 & 5760 & 1121 & 3227 & 29769 \\
\hline
\end{tabular}

If we analyze the evolution of the tourist traffic data of the hotels in the North Great Plain Region (figure 1), we can state that since 2010 the number of guests in the region has been growing steadily, showing the linear trend line. This growing trend shows the increasing demand for the North Great Plain region as a tourist destination. In the region, Hajdú-Bihar County is the most sought-after destination, as evidenced by the growing guest turnover of commercial accommodations.

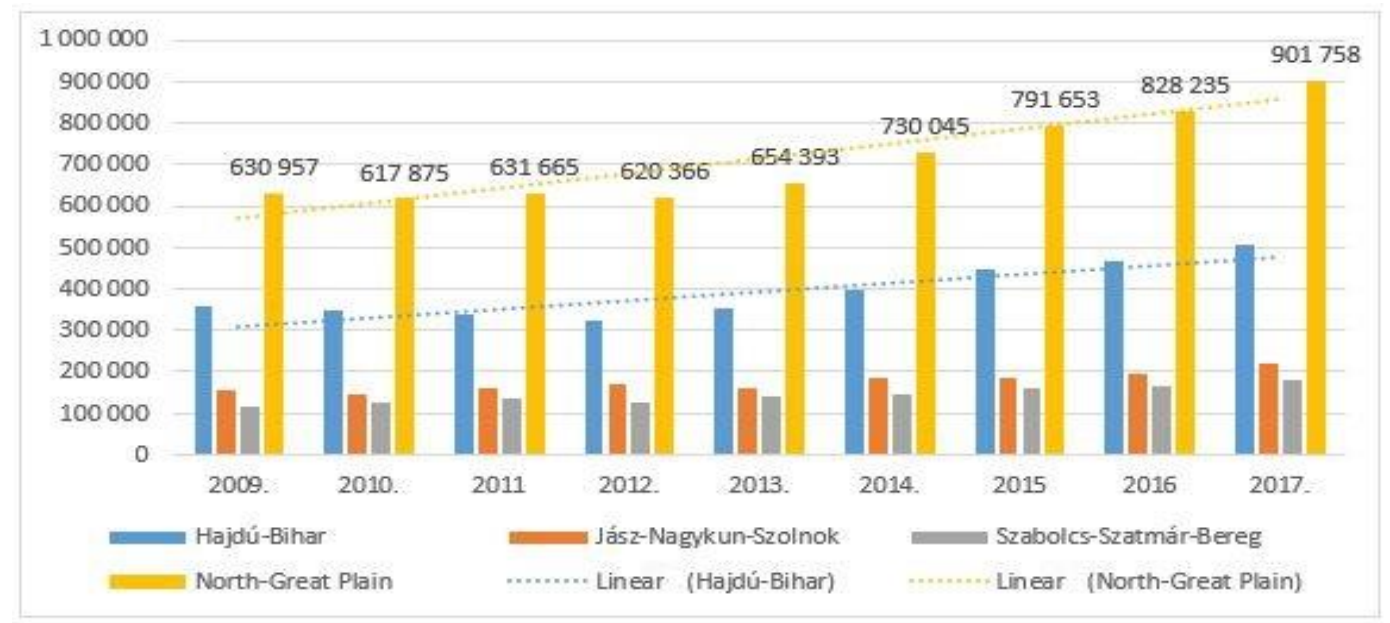

Figure 1. Visitor turnover of commercial accommodations in the North Great Plain Region 2009-2017 (person)

\section{Material and Method}

In our research, we used a questionnaire survey among three, four and five-star hotels in the North Great Plain region. By the available database, we have sent out a questionnaire for all hotels that we have compiled to measure the fitness and wellness service elements. The response rate was $86.6 \%$, 39 out of 45 hotels sent us the completed questionnaire. In our research, we sought to find out what health and wellness services are available for guests in different classifications of different hotels. The data was processed using the Spss statistical program, in addition to the basic statistics we used a chi2 test to examine the correlations. 


\section{Results}

In the course of our investigation, we analyzed the supply elements of 39 hotels in the Northern Great Plain Region.

Table 3. Distribution of the examined hotels by classifications in the North Great Plain region

\begin{tabular}{|c|c|c|c|c|}
\hline County/Hotels & $\begin{array}{c}\text { Three stars } \\
\text { pcs (\%) }\end{array}$ & $\begin{array}{c}\text { Four stars } \\
\text { pcs (\%) }\end{array}$ & $\begin{array}{c}\text { Five stars } \\
\text { pcs (\%) }\end{array}$ & Total \\
\hline Hajdú-Bihar & $3(21,4)$ & $14(58,3)$ & $1(100)$ & 18 \\
\hline Szabolcs-Szatmár-Bereg & $4(28,6)$ & $6(25)$ & 0 & 10 \\
\hline Jász-Nagykun-Szolnok & $7(50)$ & $4(16,7)$ & 0 & 11 \\
\hline Total & $14(100)$ & $24(100)$ & $1(100)$ & 39 \\
\hline
\end{tabular}

In the case of the hotels we surveyed, the hotels with higher qualification in HajdúBihar County are significantly overrepresented compared to the other two counties (chi2 = $7.34, p=0.09$ ), 18 of the 39 hotels examined are in this county (table 3 ).

Since health tourism plays a decisive role in the region and the related wellness and health services are a very important attraction, we were curious as to how many hotels use a brand value of health tourism (Kerényi et al., 2010) and how many of them use it in their name.

Out of the hotels examined, $23.1 \%$ (9pcs) of them states that the word "wellness" occurs in their name; out of these 28,6\% (table 4) have three-star classification. 20.55\% (table 5) of the four-star hotels said the same. These hotels use of the opportunity to link brand building to an old or domestic health tourism brand (Mosonyi et al., 2013).

The name of the spa appears in $15.4 \%$ (table 6 ) of the examined hotels, $28.6 \%$ (table 4) of the three-star hotels, $8.3 \%$ of the four-star hotels (table 2) said the same.

The classification of commercial hotels was previously regulated by GKM enactment 54/2003, amended IKIM enactment (Borbély and Müller, 2008), which was in effect until 2012. Based on this enactment, the number of wellness rating among the hotels we examined was the following, de-scribed in figure 2 .

Table 4. Distribution of the hotels examined, by previous wellness classification

\begin{tabular}{|c|c|c|c|c|c|}
\hline \multicolumn{7}{|c|}{ Classifications of the hotels } \\
\hline & & $\begin{array}{c}\text { Three } \\
\text { stars } \\
\text { pcs (\%) }\end{array}$ & $\begin{array}{c}\text { Four } \\
\text { stars } \\
\text { pcs (\%) }\end{array}$ & $\begin{array}{c}\text { Five stars } \\
\text { pcs (\%) }\end{array}$ & $\begin{array}{c}\text { Total } \\
\text { pcs (\%) }\end{array}$ \\
\hline $\begin{array}{c}\text { According to earlier } \\
\text { classification: the hotel } \\
\text { operates as a wellness institute }\end{array}$ & Yes & $3(21,4)$ & $9(37,5)$ & $0(0)$ & $12(30.8)$ \\
\cline { 2 - 6 } & No & $11(78,6)$ & $15(62,5)$ & $1(100)$ & $27(69,2)$ \\
\cline { 2 - 6 } & Total & $14(100)$ & $24(100)$ & $1(100)$ & $39(100)$ \\
\hline
\end{tabular}

It can be observed that $21.4 \%$ of the three-star hotels and $37.5 \%$ of the fourstar hotels operated as a wellness hotel (table 4). Although according to the new classification wellness hotels are no longer registered, they only have to be classified according to the star criteria based on quality, yet the existence of the wellness supply 
elements increases the competitiveness of the hotels as they follow the consumption trends of the health-conscious consumers of our time (Müller and Kerényi, 2009; Sőrés et al., 2012; Csirmaz and Pető, 2015; Bíró et al., 2018a).

Table 5. The appearance of wellness elements in the examined hotels

\begin{tabular}{|c|c|c|c|c|c|}
\hline \multicolumn{2}{|c|}{} & \multicolumn{4}{|c|}{ Classifications of the hotels } \\
\cline { 3 - 6 } \multicolumn{2}{|c|}{} & $\begin{array}{c}\text { Three stars } \\
\text { pcs }(\%)\end{array}$ & $\begin{array}{c}\text { Four stars } \\
\text { pcs }(\%)\end{array}$ & $\begin{array}{c}\text { Five stars } \\
\text { pcs (\%) }\end{array}$ & $\begin{array}{c}\text { Total } \\
\text { pcs (\%) }\end{array}$ \\
\hline \multirow{2}{*}{\begin{tabular}{c} 
Does the hotel offer wellness $\begin{array}{c}\text { p } \\
\text { services? }\end{array}$ \\
\cline { 2 - 6 }
\end{tabular}} & Yes & $10(71,4)$ & $22(91,7)$ & $1(100)$ & $33(84,6)$ \\
\cline { 2 - 6 } & No & $4(28,6)$ & $2(8,3)$ & $0(0)$ & $6(15,4)$ \\
\cline { 2 - 6 } & Total & $14(100)$ & $24(100)$ & $1(100)$ & $39(100)$ \\
\hline
\end{tabular}

$33(84 \%)$ of the hotels have wellness items (table 5). Based on the results, it can be stated that more of the 4-star hotels provide wellness services to the guests than the 3-star hotels. The diversity of well-ness offerings (Müller et al. 2005) and its diversification can provide health-conscious guests with a state of physical and mental well-being.

Table 6. Table The availability of fitness facilities in examined hotels

\begin{tabular}{|c|c|c|c|c|c|}
\hline \multicolumn{2}{|c|}{} & \multicolumn{4}{|c|}{ Classifications of the hotels } \\
\cline { 3 - 6 } \multicolumn{2}{|c|}{} & $\begin{array}{c}\text { Three stars } \\
\text { pcs (\%) }\end{array}$ & $\begin{array}{c}\text { Four stars } \\
\text { pcs (\%) }\end{array}$ & $\begin{array}{c}\text { Five stars } \\
\text { pcs (\%) }\end{array}$ & $\begin{array}{c}\text { Total } \\
\text { pcs (\%) }\end{array}$ \\
\hline \multirow{3}{*}{$\begin{array}{c}\text { Does the hotel have a } \\
\text { fitness facility? }\end{array}$} & Yes & $2(14,3)$ & $10(41,7)$ & $1(100)$ & $13(33,3)$ \\
\cline { 2 - 6 } & No & $12(85,7)$ & $14(58,3)$ & $0(0)$ & $26(66,7)$ \\
\cline { 2 - 6 } & Total & $14(100)$ & $24(100)$ & $1(100)$ & $39(100)$ \\
\hline
\end{tabular}

Also, we also examined whether the hotels have a fitness room. The results showed that $41.7 \%$ of the 4 -star hotels and only $14.3 \%$ of the 3 -star hotels had a fitness room and provided this opportunity to their guests (table 6). The former wellness hotel enchantment required the provision of air conditioning rooms for guests, which may have emphasized the wellness concept related to the development of physical health as this kind of sporting service is not a seasonal supply element provided throughout the year.

Recreational trends show that regular health-conscious exercise is essential for today's health-conscious consumers, who want to do it during their stay (Lenténé et al., 2018).

Table 7. The appearance of leisure sports services in the examined hotels

\begin{tabular}{|c|c|c|c|c|c|}
\hline \multicolumn{2}{|c|}{} & \multicolumn{4}{|c|}{ Classifications of the hotels } \\
\cline { 3 - 6 } & $\begin{array}{c}\text { Three stars } \\
\text { pcs (\%) }\end{array}$ & $\begin{array}{c}\text { Four stars } \\
\text { pcs (\%) }\end{array}$ & $\begin{array}{c}\text { Five stars } \\
\text { pcs (\%) }\end{array}$ & $\begin{array}{c}\text { Total } \\
\text { pcs (\%) }\end{array}$ \\
\hline $\begin{array}{c}\text { Is there an opportunity for } \\
\text { leisure sport, east or aerobic } \\
\text { type of sport? }\end{array}$ & Yes & $5(35,7)$ & $9(37,5)$ & $0(0)$ & $14(35,9)$ \\
\cline { 2 - 6 } & No & $9(64,3)$ & $15(62,5)$ & $1(100)$ & $25(64,1)$ \\
\cline { 2 - 6 } & Total & $14(100)$ & $24(100)$ & $1(100)$ & $39(100)$ \\
\hline
\end{tabular}


For leisure sports, $35.7 \%$ of 3 the star and $37.5 \%$ of the 4 -star hotels provide opportunity for their guests (table 7). The expectation for leisure sports is that it should be fun, excitement-centered and have a wide range of movement repertoire according to the expectations of different target groups. In our previous survey, we have evaluated the leisure sports offerings of the hotels in the counties of the region. The results showed that most hotels are located in Hajdú-Bihar County, and the most popular in leisure sports in them are: yoga, aerobics, bicycle tours and water training (Lenténé et al., 2018).

Among sports services, the most popular among hotel guests, are suitable for prevention, the improvement of fitness level and for the support of the physical, psychological and social well-being, which fact is also confirmed by trends (Müller and Bácsné, 2018; Bendíková, 2017).

Recreational sports offerings are available in many domestic and foreign hotels, as tourist trends show that active holidays are replacing passive holidays more and more (Müller et al., 2016). Health conscious guests require a variety of active pack refill services during their stay.

\section{Conclusions}

Tourism and health tourism product development is vital for the North Great Plain region, as the development of the tourism market is based on reasonable conditions. This is especially important given that the region's commercial accommodation has been able to increase its number of guests since 2010. Quality parameters should also be taken into account in the development of supply elements, as the extensive and intensive development of services together represents competitiveness in tourism (Molnár et al., 2014; Bíró et al., 2018b). The wellness and sports offer are predominantly seen in the hotels in the North Great Plain region as additional services. The expansion of these services is justified by to-day's recreational trends, which show that regular exercise is important for healthconscious consumers, who want to do it during their holidays.

Our research has shown that the inclusion of wellness offerings in the hotels of the Northern Great Plain region is markedly marked. The addition of wellness elements in the offers of the hotels is definitely an essential element of competitiveness, as it meets increasing demand. The word well-ness appears in many names of the Northern Great Plain region's hotels, thus in the marketing communication sends a message to the guests, this attraction factor is used predominantly in the promotion. Fitness and sports offerings are also available in many hotels, which can provide active leisure for health-conscious consumers.

\section{Acknowledgment}

This study was supported by the EFOP-3.6.2-16-2017-00003 project which is financed by the European Union and the European Social Fund. 


\section{References}

Árva, L., Könyves, E., Mondok, A., \& Csizmár, J. (2008). The economics of tourism. Szolnok, Magyarország: Szolnoki Főiskola, $240 \mathrm{p}$ (in Hungarian).

Bakucz, M., Bozóti, A., Kincses, Á., Köbli, Á., Pótó, Zs., \& Tóth, G. (2016). The demand-side evaluation on West Trans-danubia's medical and thermal baths. In: Fürdőtelepülések versenyképességi vizsgálata néhány magyar és Közép-európai régióban. (szerk: Bakucz Márta-tegzes Andrea). 2016. Pécsi Tudományegyetem, Pécs. p. 188, ISBN:978-963-429-056-8 (in Hungarian).

Barta, G., Pálinkás, R., \& Müller, A. (2011). The Role of the Saliris Thermal Spa's bath in the tourism and recreation. Acta Academiae Agriensis Nova Series Tom-Sectio Sport, 38, 5-3.

Bendíková, E. (2017). Theory of health, movement and lifestyle of human beings. 1. vyd. - Debrecen: University of Debrecen, 164 p. ISBN 978-963-473-219-8 (in Hungarian).

Biró, M., Lenténé Puskás, A., Bácsné Bába, É., \& Müller, A. (2018a). Role of the northern great plain region baths in wellness tourism and recreation in Hungary. Slovak Journal of Sport Science, 3(1):48-62.

Biró, M., Lenténé Puskás, A., Dobay, B., \& Müller, A. (2018b). Role of the North Great Plain baths in the wellness tourism. In: Balogh, László (szerk.) Fókuszban az egészség. Debrecen, Magyarország : Debreceni Egyetem Sporttudományi Koordinációs Intézet, pp. 38-49 (in Hungarian).

Borbély, A., \& Müller, A. (2008). The context and methodology of the bodyand soul's harmony. ValóságTérkép-6. PEM tanulmányok (Kiadja: a Professzorok az Európai Magyarországért Egyesület, Bp. szerkeszti: dr. Koncz István) 211 p. (in Hungarian).

Bozóti, A. (2015). The regional comparison of the analysis of the small towns and new baths competitiveness. Fürdővárosok, Történelmi ismeretterjesztő Társulat egyesület, Budapest. ISBN: 978-963-89727-4-3, pp. 203-217 (in Hungarian).

Csirmaz, É., \& Pető, K. (2015). International trends in recreational and wellness tourism. Procedia economics and finance, 32, 755-762.

Darabos, E. (2015). Role of tourism in the world economy; evolution of numbers and wages of employees in the sector in Hungary. Acta Oeconomica Universitatis Selye, 4(1), 42-50.

Darabos, É., \& Nagy, T.O. (2018). Role of grants for tourism purposes in development of the Northern Great Plain region. International Journal Of Engineering and Management Sciences, 3(4): 365-376.

Dávid, L., Remenyik, B., \& Szűcs, Cs. (2013). Special health tourism products in the Bükk and Mátra regions. In: Melanie, Smith; László, Puczkó (szerk.) Health, tourism and hospitality : spas, wellness and medical travel.New York, Amerikai Egyesült Államok : Routledge, pp. 335-339.

Go, F., \& Govers, R. (2000). Integrated quality mangement for tourist destinations: a european perspective on achieving competitiveness. Tourism management, 21(1): 9-22.

Hegedüs, V. (2006). Changes in the conceptual system of and demands on health tourism in Hungary. Földrajzi Értesítő, 3-4. ISBN: 9789630644587 (in Hungarian).

Herman, G. V., Deac, A. L., Ciobotaru, A. M., Andronache, I. C., Loghin, V., \& Ilie, A. M., (2017). The role of tourism in local economy development. Bihor County case study. Urbanism. Architecture. Constructions/Urbanism. Arhitectura. Constructii, 8(3), 265-274.

Herman, G.V., Peptenatu, D., Grama, V., \& Pintilii, R.D. (2018). Tourism and Local Development. Study Case: Băile Felix-Băile 1 Mai Tourism System, Bihor County, Romania. Analele Universitatii din Oradea, Seria Geografie, 28(1): 131-137.

Ilie, A. M., Herman, G. V., Ciobotaru, A. M., Grecu, A., Radu, R. A., Visan, M. C., \& Giurgia, M., (2017). The role of tourism in structural dynamics of the economic profile of Sighisoara city. Urbanism. Architecture. Constructions/Urbanism. Arhitectura. Constructii, 8(4), 377-386.

Kerényi, E., Müller, A., Szabó, R., \& Mosonyi, A. (2009). Analysis of Agárd, Komárom and Papa's Thermal and Experiences bath according the guest's satisfaction. In: Kerényi, Erika (szerk.) Egészségügyi marketing és telekommunikáció. Mátraháza, Magyarország pp. 56-67 (in Hungarian).

Kerényi, E., Müller, A., Könyves, E., Lázárné Fodor, I., \& Mosonyi, A. (2010). Tourism brand and product development opportunities for health tourism in the Northern Hungary and Northern Great Plains Regions. Acta Academiae Agriensis, 27, 67-73.

Kincses, Gy. (2005). The Hungarian perspectives of health tourism - the sectoral focus of a renewed strategy. Egészségügyi Stratégiai Kutatóintézet, Budapest, 2009. Magyar Turisztikai Hivatal: Tájékoztatás „A fürdőfejlesztésekkel kapcsolatban a hazai termálvízkészlet fenntartható hasznosításáról és a használt víz kezeléséről szóló hidrogeológiai kutatásról” Budapest (in Hungarian). 
Kiss, K., \& Török, P. (2001). The international supply and demand trends of health tourism. Turizmus Bulletin, 5(3), 7-14.

KSH (2017). The situational picture of the sectors of tourism and hospitality. http://www.ksh.hu/docs/hun/xftp/idoszaki/jeltur/jeltur17.pdf

Lengyel, A. (2016). Tourism, meditation, sustainability. APSTRACT: Applied Studies in Agribusiness and Commerce, 10(1033-2016-84303), 81.

Lenténé, Puskás, A., Biró, M., Dobay, B., \& Pucsok, J.M. (2018). Explore The Sup-Ply Elements and Services of Leisure Sports in the Northern Great Plain Region of Hungary. In: "Sport science in motion" Proceedings from the scientific conference = Válogatott tanulmányok a tudományos konferenciáról Komárno, May 17th-19th, 2018. Ed.: Jaromír Simonek, Beáta Dobay, Univerzita J. Selyeho v Komárne, Komárno, 330-339, 2018. ISBN: 9788081222450 (in Hungarian).

Lövei-Kalmár, K. (2017). The significance of spas in the development of the north great plain region's health tourism. The importance of baths in the development of Northern great plain's health tourism. Köztes-Európa, 9(1-2), 205-213 (in Hungarian).

Mező, F., \& Maczik, E. (2010). Health tourism in focus: possible break out points in the North Great Plain Region. In. Polgári szemle.5. évf. 4. szám. https://polgariszemle.hu/archivum/54-2010-augusztus-6evfolyam-4-szam/394-fokuszban-az-egeszsegturizmus-lehetseges-kitoeresi-pont-az-eszak-alfoeldiregioban (in Hungarian).

Michalkó, G., \& Rácz, T. (2011). Health tourism and the quality of life in Hungary: chapters of the connections between health, travel and well-being in Hungary. Budapest, MTA. Földrajztudományi Kutatóintézet, 179 p. (in Hungarian).

Molnár, C., Dávid, L., \& Vasa, L. (2014). Health tourism in Hungary: history, its revaluation and tendencies. In: Laskowski, M; Sauer, P (szerk.) Innovations and sustainable development : actual research problems in Eastern Europe. Lublin, Lengyelország : Technical University of Lublin, 2014 pp. 137-153.

Molnár, Cs., Kincses, Á., \& Tóth, G. (2010). The impact of spa development in East Hungary, comparison of Hajdúszoboszló, Mezőkövesd and Orosháza. In: Turizmus Bulletin. XIII.évf.4.szám. p. 20-32.

Mosonyi, A., Lengyel, A., \& Müller, A. (2013). Branding potential of spas in the Northern Plain and the Mid-Transdanubian Regions. APSTRACT: Applied Studies in Agribusiness and Commerce, 7(10332016-83991), 97.

MTÜ (2017). The main results of the Hungarian Commercial Accomodations in 2017. https://mtu.gov.hu/documents/prod/Kereskedelmi_-szallashelyek_adatai_2017_1.pdf

Müller, A. (2018). Health tourism in Hungary. In: Jaromír, Šimonek; Beáta, Dobay (szerk.) Sport science in motion : proceedings from the scientific conference. Športová veda v pohybe: recenzovaný zborník vedeckých a odborných prác z konferencie. Mozgásban a sporttudomány: válogatott tanulmányok a konferenciáról.Komárno, Szlovákia : Univerzita J. Selyeho, pp. 8-15 (in Hungarian).

Müller, A., \& Bácsné Bába, É. (2018). The connection of sport and healthy lifestyle. Létavértes, Magyarország : Létavértes SC '97 Egyesület, 96 p. (in Hungarian).

Müller, A., \& Kerényi, E. (2009). Trends and customer behaviour in health care. Egészségügyi marketing és telekommunikáció című konferencia kiadványkötete, 11-19 (in Hungarian).

Müller, A., \& Könyves, E. (2006). The opportunities of health tourism in the North Great Plain Region. Acta Academiae Paedagogicae Agriensis Nova Series: Sectio Sport, 33, 132-143.

Müller, A., \& Kórik, V. (2009). The role of the North Great Plain's baths in tourism and recreation. Economica 2, 58-72.

Müller, A., \& Szabó, R. (2009). Analysis of Agárd, Komárom and Papa's Thermal Bath, According the Guest's satisfaction. Acta Academiae Pedagogicae Agriensis, 36, 89-101.

Müller, A., Barcsák, B., \& Boda, J.E. (2016a). Health tourism the cavebath of Miskolctapolca. In: György, Juhász; Enikő, Korcsmáros; Erika, Huszárik (szerk.) Korszerű szemlélet a tudományban és az oktatásban. Gazdaságtudományi szekció : Zborník medzinárodnej vedeckej konferencie Univerzity J. Selyeho - 2016 „Súcasné aspekty vedy a vzdelávania" . Sekcie ekonomických vied.Komárno, Szlovákia : Selye János Egyetem, pp. 233-245. , 13 p. (in Hungarian).

Müller, A., Boda, E. J., Ráthonyi, G., Ráthonyi-Odor, K., Barcsák, B., Könyves, E., \& Bendíkova, E. (2016). Analysis of the Cavebath of Miskolcatapolca's brand elements and guests satisfaction. Apstract: Applied Studies in Agribusiness and Commerce, 10(4/5), 155-160.

Muller, A., Kerenyi, E., \& Konyves, E. (2011). Effect of climate therapy and rehabilitation in Mátra Medical Institute. APSTRACT: Applied Studies in Agribusiness and Commerce, 5(1033-2016-84154), 39-42. 
Müller, A., Könyves, E., \& Szabó, R. (2005). The presentation of the diverse supply of wellness tourism. Iskolai Testnevelés És Sport - Elméleti Módszertani És Információs Szaklap, 27, 29-34. (in Hungarian).

Müller, A., Pfau, C., Gabnai, Z., Bácsné Bába, É., Borbély, A., \& Pető, K., (2018). Development opportunities of health, wellness and sports services in medical tourism based on a research study. International Journal of Economics and Management Studies (SSRG-IJEMS) 3(4): 101-114.

Müller, A., Szabó, R., Kerényi, E., \& Mosonyi, A. (2009). Bath research in the Central Trans-danubian Region. Acta Academiae Pedagogicae Agriensis, 36, 65-77.

Mundruczó Györgyné-Szennyessy, J. (2005). The economic impact of the Széchenyi Plan's investments. Turizmus Bulletin, 9. évf. 3. sz., Budapest (in Hungarian).

Myers, J. E., Sweeney, T. J., \& Witmer, J. M. (2000). The wheel of wellness counseling for wellness: A holistic model for treatment planning. Journal of Counseling \& Development, 78(3), 251-266.

Rulle, M., Hoffmann, W., \& Kraft, K. (2010). The strategy of success in health tourism. Analyse zur Erwartung und Zufriedenheit von Gästen. Berlin: Erich Schmidt Verlag GmbH \& Co. KG.

Sőrés, A. (2013). The impact of health tourism on the quality o life in Hajdúszoboszló. Doktori értekezés. Debreceni Egyetem, Ihring Károly Gazdálkodás- és Szervezéstudományi Doktori Iskola, Debrecen. 158 p. (in Hungarian).

Sőrés, A., Pető, K., \& Csipkés, M. (2012). Examining life quality in Hajdúszoboszló Tourist Area, with a particular focus on health conditions, Agrárinformatika / Journal Of Agricultural Informatics 3(1): 1-9.

Sziva, I. (2010). Lets clear the air...the impoundment of the definition of health toursim and the assorted bibliography of it's trends. Turizmus Bulletin, 14(4), 73-76. 